(This was first published in Shofar: An Interdisciplinary Journal of

Jewish Studies, vol 27, no 3, 2009, pp. 102-127)

\title{
Jews Dreaming of Acceptance: From the Brill Building to Suburbia with Love
}

'This is the way

I always dreamed it would be

The way it is

When you are holding me.'

'I Can Hear Music’ Jeff Barry, Ellie Greenwich, Phil Spector (1966)

Ken Emerson reminds us that the 'Brill Building sound' actually came not only from the Brill Building at 1619 Broadway but also, and at least as importantly, from 1650 Broadway. ${ }^{1}$ Indeed, the bulk of the composers I will focus on in this article worked at 1650 Broadway where, from May 1958, Aldon Music was located. This music publishing enterprise was started by twenty-one year old Don Kirshner and forty-two year old Al Nevins who had played with the Three Suns. They immediately signed Neil Sedaka and Howard Greenfield and, by 1962, employed eighteen composers, all between the ages of nineteen and twenty-six. These included the composing pairs most associated with the 'Brill Building sound': Carole King and Gerry Goffin, Barry Mann and Cynthia Weil, Jeff Barry and Ellie Greenwich, in addition to Sedaka and Greenfield. As Mick Brown remarks in his biography of Phil Spector with only slight exaggeration: 'There wasn't a writer at Aldon who wasn't Jewish. $^{2}$

In an important article on the legacy of the Brill Building music, Ian Inglis writes that:

'while it may be difficult to argue that there was a specific Brill Building "sound", it has been noted that certain themes and components do recur in many of the songs. While they generally conformed in their structure (utilizing the AABA form) and their 
subject matter (personal relationships), they were in other ways quite distinctive, employing relatively complex melodies and innovative harmonic progressions that became recognized as key characteristics of Brill Building compositions. ${ }^{3}$

This music was incredibly popular. Commenting on the innovation of female composers, Inglis tells us that King, Greenwich and Weil helped 'to compose more than 200 songs that reached Billboard's Hot 100 Singles chart. ${ }^{4}$

At a time when record buying in the United States was still very segregated, the audience for Brill Building music of this type was predominantly white, and included Jews and ethnic groups such as Italians. The music's emphasis on melody and harmony, as opposed to beat and rhythm, placed it within the white, Europeanoriginated popular music tradition. Brown incisively comments that, 'Kirshner's writers...were 'normal Jewish kids,' as he puts it, whose songs both shaped and reflected the conservative dreams and aspirations of most American teenagers. ${ }^{5}$ In this, the accomplishment of these Jews was similar to that of the Jews who founded the Hollywood film industry. As Neil Gabler writes in An Empire of Their Own:

'Ultimately, American values came to be defined (sic) largely by the movies the Jews made. Ultimately, by creating their idealized America on the screen, the Jews reinvented the country in the image of their fiction. ${ }^{6}$

I will be arguing that, in expressing Jewish utopian fantasies of acceptance in America through these songs of love, these Jewish songwriters were also both shaping and expressing the desires of mainstream, white American youth. I should state here, right at the start, that I am not suggesting that these Jewish songwriters were conscious of what they were doing. Rather, as both Jews and as Americans, they were the product of their time and, as such, were expressing the fantasies of Jews in the United States during the 1950s and early 1960s in the same way as the Hollywood Jews were in the early decades of the twentieth century, and, also, expressing the desires of young, white Americans-members of the newly minted category of teenagers. It was during this time, as we shall see, that Jews were, indeed, becoming accepted in the United States as white.

Placing the Brill Building songs in their social context 
Inglis correctly remarks that, 'many commentaries on popular music either overlook [the Brill Building sound's] significance completely by failing to mention it at all or else dismiss it as a mildly interesting historical footnote by giving it only scant attention.' ${ }^{7}$ This is because most histories of post-World War 2 popular music start from the premise that rock'n'roll was the most important musical form of the era. However, from a cultural perspective, the Brill Building sound was at least as important because it was more popular with a broad, white, teenage audiencesomething easily demonstrated in the popularity of these songs from the mid-1950s to the mid-1960s. Where the defining musical influence on rock'n'roll was rhythm and blues, the Brill Building sound harked back to the much whiter melodies of Tin Pan Alley. Brown, as we have seen, describes the Brill Building songs as conservative. However, for my purposes here, it would be better to think of them as producing and reproducing aspects of the dominant culture.

In histories of American popular music, the songs from the Brill Building era are positioned between the decline of rock'n'roll through the second half of the 1950s and the mid-1960s British Invasion spearheaded by the Beatles' tour of February 1964. In this musical history the success of the Brill Building songwriters was a consequence of the recuperation of rock'n'roll, and what Grace Palladino describes as its 'beat, sex, rebellion, fun, ${ }^{8}$ into a conservative, entertainment tradition which had, as Michael Billig puts it, 'a continuity with the earlier years of Tin Pan Alley. ${ }^{9}$ Billig quotes from the Virgin Encyclopedia of Sixties Music, giving an insight into the generally negative attitude towards the Brill Building era music which describes it as 'conveyor-belt produced pop.' 10 The Beatles and the other groups of the British Invasion, most obviously the Rolling Stones, are understood as stimulating the garage band movement in the United States and offering white teenagers more engaging music than the melodic songs of love churned out by the Brill Building composers.

There are, however, significant problems with this music-focused history. First of all, it is clear that, by 1964, there was already a decline in the popularity of Phil Spector's 'Wall of Sound' productions, most of which were written by Brill Building composers. Second, the Brill Building composers continued to have hits through the second half of the 1960s, albeit in radically reduced numbers. Third, many of the hits of the British Invasion groups were written by Brill Building composers. Emerson notes that: 'John Lennon and Paul McCartney proclaimed King 
and Goffin their favorite songwriters, ${ }^{, 11}$ and Please, Please Me contained a version of Goffin and King’s 'Chains’ and Burt Bacharach and Hal David’s 'Baby It’s You' and also Bert Berns' 'Twist And Shout.' Inglis incisively comments that:

'It is clear that an important foundation of [the Beatles'] success was continuity rather than change. The Beatles did not provide a superior or radical alternative to the music being produced in the United States, but did deliberately utilize much of that music they admired so greatly as an important component within their overall commercial strategy. ${ }^{12}$

Moreover, fourth, the garage band revolution was already taking place. Philip Ennis tells us that, 'in 1963, even before (sic) the Beatles arrived on the scene, it should be noted, there began a huge growth ${ }^{13}$ in the sale of guitars. Indeed, in 1963 Florence Greenberg, who, as we shall see, owned Scepter Records, bought the Kingsmen's version of 'Louie Louie,' the archetypal garage band song, from the small Seattle label, Jerden. ${ }^{14}$ Released on Greenberg's subsidiary label, Wand, 'Louie Louie' reached number 2 on the Billboard chart and stayed there for sixteen weeks.

The Brill Building sound, and I am including Spector's productions, was beginning to show a marked decline in popularity during 1963. At the same time the garage sound was increasing in importance. If, generally speaking, the ideological drive of the Brill Building sound was the fantasy that love underpins the perfect relationship and that the perfect relationship brings a fulfilled life, then, generally speaking, garage bands offered a criticism of this. In his book, Sixties Rock, Michael Hicks provides this definition of a garage band:

'A garage is a rougher, dirtier place than where humans typically reside; a place to store heavy machinery and marginally useful possessions. It is a place of noise and alienation, a psychological space as much as a physical one. In this light "garage band” implies a distancing from more respectable bands (and from more respectable social enterprises in general)., 15

For 'more respectable bands' here, we can, historically, read the Brill Building sound. This was the music and ideology of the home against which the garage bands, and their audience, were reacting. The garage sound was an expression of disillusionment. 
We can take the years 1959 to 1963 as the high point of the Brill Building sound. Socially speaking, it was, as we shall see, also the time when the average age at marriage fell to its lowest in the United States in the twentieth century. These years were, in addition, the high water mark of post-Second World War suburbanization and, in particular, of the movement of Jews out of the cities to the new suburbs. Along with this movement Jews found themselves being whitened. The desire of the generation that made this move was the same as the desire of their migrant grandparents-for Americanization and acceptance into (white) American society. Structurally speaking, it is this desire, I will argue, which found expression in the songs of the Brill Building era, in the fantasies of love, marriage and homely relationships.

1963 marks the beginning of a general, white disillusion with the suburban dream but it marks a greater Jewish disillusion because American Jews had more at stake. In this context it should come as no surprise that it was a Jewish woman, originally from the mid-Western heartland, Bettye Goldstein of Peoria, who had become Betty Friedan of suburban Parkway Village, Queens, and latterly of even more suburban Rockland County, New York, who should be the first to voice white women's discontent in their suburban life. ${ }^{16}$ Published in 1963, The Feminine Mystique begins by eloquently stating (white) women's, and especially Jewish women's, disenchantment:

'The problem lay buried, unspoken, for many years in the minds of American women. It was a strange stirring, a sense of dissatisfaction, a yearning that women suffered in the middle of the twentieth century in the United States. Each suburban wife struggled with it alone. As she made the beds, shopped for groceries, matched slipover material, ate peanut butter sandwiches with her children, chauffeured Cub Scouts and Brownies, lay beside her husband at night—she was afraid to ask even of herself the silent question-“'Is this all?",17

While Friedan asked this question on behalf of all women in suburbia, what Jewish women and their husbands had found out, in addition, was that being whitened did not bring acceptance. As Jews they remained excluded from the WASP culture of suburbia. 


\section{From Leiber and Stoller to the Shangri-Las}

We do need to remember, though, that Aldon Music in the late 1950s is only one part of the Brill Building story. There is an earlier part which feeds into and overlaps with this narrative. Here we can start with Jerry Leiber and Mike Stoller who began writing songs together at the beginning of the 1950s. In August 1952 they had their first major success when the rhythm and blues singer Big Mama Thornton recorded their composition 'Hound Dog.' ${ }^{18}$ Leiber was born in 1933 and 'grew up in a Yiddish-speaking household in a largely Catholic neighbourhood on the edge of Baltimore's black ghetto.' ${ }^{19}$ After the death of his father, Leiber's family moved to Los Angeles in 1945. Born the same year in Belle Harbor, Long Island, Stoller spent twelve years growing up in Sunnyside, Queens, before his parents moved the family to Los Angeles in 1949. By this time Stoller had developed an interest in AfricanAmerican music and even taken lessons from the stride pianist, James P. Johnson. ${ }^{20}$

Leiber and Stoller's early material was written for African-American artists and aimed at an adult, Black audience. However, starting with the songs they wrote for a white group, the Cheers, including 'Black Denim Trousers And Motorcycle Boots,' of which more later, by the time the composers moved to Manhattan, and 1650 Broadway, their songs were increasingly emphasising melody and harmony, and had lyrics that could appeal to the white, teenage market. There was another change taking place in their music. Emerson identifies it in a comparison of the Coasters' 'That Is Rock \& Roll' with a Drifters' song recorded three weeks earlier, 'There Goes My Baby':

'For the first time the Coasters' high spirits seem forced. The record's falsity reflected the beginning of a shift that "There Goes My Baby; marked but no one recognized at the time. ${ }^{21}$

The year is 1959. The songs Leiber and Stoller wrote for the Coasters can be understood as marking a transition between their early Black-focused material and their later work, often still sung by African-American artists, most importantly the Drifters, but tailored more to the taste and interest of a white, teenage audience. A good example is 'Yakety Yak,' which reached number 1 in 1958. Emerson suggests that, for Leiber and Stoller, the origins of the song may have lain in the Silhouettes' 'Get A Job': 'For the necessity of finding employment, a harsher reality in black 
families than in many white ones, [Leiber] substituted the household chores that were a hassle for white as well as black teenagers. ${ }^{, 22}$ Key to the commonality here was the sense of oppression experienced by African-American adults and (white) teenagers. However, sung by an African-American group, it is precisely the absurdity of comparing the predicament of unemployed African Americans with the life of white teenagers which provides the source of the song's humour. Leiber and Stoller's early teen songs-unlike their songs for African-American adults-tended to function lyrically as observational commentary. With 'There Goes By Baby' the music's melodrama and the agony in the lyrics are the direct expression of the end of a relationship. The musical style of the song, including its use of strings and emphasis on melody, pointed it at the white, pop market rather than the Black market. It reached number 2 on the pop chart. This is the moment when Leiber and Stoller's songs take on the same teen concerns as the songs of the writers working for Aldon Music.

Doc Pomus came out of a similar background to Leiber and Stoller. Eight years older than them, Pomus was born Jerome Felder. His father had migrated from Vienna and his mother, Millie Goldstein, from London. Pomus was brought up in Williamsburg, Brooklyn. He contracted polio when he was six. Nevertheless, as a teenager Pomus began to sing in Black clubs, and then started to write songs. He went to work for Atlantic where he met Leiber and Stoller and wrote songs recorded by the blues shouter, Big Joe Turner, and Ray Charles. However, in 1955 Pomus decided that the future lay in writing songs for the white teen market so he teamed up with Mort Shuman who was nineteen at the time. Shuman's parents came from Warsaw and he spoke Yiddish before he went to school. ${ }^{23}$ He was brought up, like Sedaka, who was a year behind him at school, in Brighton Beach.

As a song writing pair working out of 1650 Broadway, Pomus and Schuman’s first success was with Fabian who recorded their 'Turn Me Loose' among other hits. They went on to further success with other Italian-American teen idols, Frankie Avalon and Bobby Rydell. At this time, Italians were also making the American transition into being accepted as white. The popularity among white teenagers of these singers singing pop songs rather than ethnic-originated songs was a part of this assimilation. Like Leiber and Stoller, Pomus, with Shuman's help, moved from writing melodic rhythm and blues songs for African-American singers and the Black 
market, to writing melodic pop songs sung by white, and sometimes Black artists, inflected with a rhythm and blues sensibility for a white, teenage audience. Perhaps their greatest success was with the Drifters' recording of 'Save The Last Dance For Me’ which was a number 1 on the pop chart in 1960 .

There are other Jews who are materially important to the story I want to tell here. Florence Greenberg was born in 1913, making her twenty years older than Leiber and Stoller. By the 1950s she was a housewife in Passaic, New Jersey, with two children in school. Like the women described by Friedan, Greenberg was looking for something to occupy her time and had a friend who had a contact in the music industry. About this time, in a story that has been often retold, her daughter heard a group of African-American girls singing at school and suggested to her mother that she should listen to them. Greenberg became the Shirelles' manager and put them on the record label she was just starting up called Tiara. Having released one single in 1958, 'I Met Him On A Sunday,' which the Shirelles had written, Greenberg sold the label to Decca. In 1959 Greenberg started another label, Scepter, and resigned the Shirelles. By 1960 she had moved the label's office into 1650 Broadway. Looking for songs for the Shirelles, she was offered a song by Goffin and King whom Kirshner had newly signed to Aldon Music. 'Will You Love Me Tomorrow,' a story of a young girl's need for reassurance before letting her boyfriend go 'too far,' became number 1 on the pop chart in 1961 .

Greenberg continued to work closely with Aldon Music and other writers at 1650 Broadway. Bacharach, who, with David, had been writing songs for Scepter artists, discovered the African-American Dionne Warwick, who Scepter signed in 1962. Over the next ten years Warwick had thirty-one hits with Bacharach and David compositions. In 1976, Greenberg retired and sold Scepter. In its time, and especially in the early 1960s, Scepter was the most successful independent label and this success was underpinned by Jewish Brill Building composers. It would not be too much of an exaggeration to say that Scepter was to a significant extent responsible for defining the teenage pop sound of the 1960s.

Another person crucially important to my story, as I have already indicated, is Phil Spector. Spector was born in 1939. His grandparents on both sides had migrated from the Ukraine in the early years of the century along with the children who would be Spector's parents. He grew up in the working-class area of Soundview, in the 
Bronx. Spector's father committed suicide in 1949 and, in 1953, his mother moved the family to Los Angeles. Spector's childhood was unhappy. His highly-strung sister was subject to dramatic mood swings that would see her institutionalised later in her life. His mother was extremely controlling. Mick Brown writes about the strained relationship between mother and son' noting that, 'the pair bickered constantly. ${ }^{24}$ Brown expands on this:

'Whatever the starting point of the arguments—school grades, money, Phil's 'unsuitable' friends-they would inevitably progress to the family's festering sore, the death of Ben. 'Phil would be berated with that,' one friend remembers. Bertha would say, "Your father killed himself because you were a bad child.” And then he would say, "Daddy killed himself because of you”.,25

Spector's first record to top the singles chart, which he wrote and sang on, along with Marshall Lieb, Harvey Goldstein and Annette Kleinbard as the Teddy Bears, was 'To Know Him Is To Love Him.' It was released in 1958. The title came from the epitaph on Spector's father's gravestone with the 'was' replaced by 'is.' The song is, as Brown writes, 'a memoriam disguised as a pop song. ${ }^{26}$ More, it is a song that draws on Spector's unhappy family past to create a fantasy of love, a dream where, through Kleinbard's yearning lead vocal, the girl, just knowing the man, loves him: 'To know him is to love him, and I do.' As I have already suggested, love, as we shall find again in other contexts, was for these Jews, and Spector in particular, the foundation for a utopian future.

By 1961 Spector was honing his craft as a writer and, more importantly, as producer. He had also begun working with Kirshner and his composers at Aldon Music. While they were not the first of the girl groups, Greenberg's work with the Shirelles provided the template for the girl group sound which Spector later refined. In 1961 he co-wrote and produced the African-American girl group the Crystals' 'There’s No Other (Like My Baby)' which reached number 20 on the chart and, in 1962, he produced the group’s 'Uptown,' written by Aldon Music’s Mann and Weil. It climbed to number 13. By this time, Spector was beginning to develop his 'Wall of Sound' production, which Brown describes this way: 
'Marshalling armies of guitars and keyboards and brass and drums, celestial sleigh-bells, and voices keening like angels, he made records of a hitherto unconceived-of grandeur and majesty, elevating the themes of teenage love and heartache to the epic proportions of Wagnerian opera-'little symphonies for the kids,' as he put it. Spector crammed emotion into a bottle and uncorked it. ${ }^{27}$

The peak period of Spector's popularity with the 'Wall of Sound' ran from around 1962 - the Crystals' 'He’s A Rebel' made number one in that year-to 1965 when the Righteous Brothers reached number one with 'You've Lost That Lovin’ Feeling,' which was another Mann/Weil composition also co-written by Spector. By the time of Tina Turner's remarkable version of 'River Deep-Mountain High,' written by Aldon Music’s Barry and Greenwich, with input from Spector and released in 1966 the appeal of Spector's work was fading. 'River Deep-Mountain High' only got to number 88 .

In the years between 1962 and 1965, Spector produced a string of love songs by the Crystals, 'He's Sure the Boy I Love' (Mann/Weil), 'Da Doo Ron Ron' (Barry/Greenwich/Spector), 'Then He Kissed Me’ (Barry/Greenwich/Spector), 'Little Boy' (Barry/Greenwich/Spector), the Ronettes 'Baby I Love You' (Barry/Greenwich/Spector), '(The Best Part Of) Breaking Up’ (Andreoli/Spector), 'Do I Love You' (Andreoli/Poncici/Spector), 'Walking In The Rain' (Mann/Weil/Spector) and Darlene Love, 'Wait 'Til My Bobby Gets Home' (Barry/Greenwich/Spector), ‘A Fine, Fine Boy’ (Barry/Greenwich/Spector). In all these songs, almost all written by Jews, produced by a Jew, and sung by young African-American women, the utopian fantasy of love providing the basis for the perfect, totally fulfilling relationship is reinforced by the mountainous sound which is designed to overwhelm the listener.

Brown writes that:

'At Gold Star [the recording studio where Spector worked], the huge speakers in the control room, and the lashings of echo applied to each song, would transform the music into something that seemed to have a life of its own. 'The control room at Gold Star was the greatest listening environment imaginable. It just consumed you, enveloped 
you —all of the sound coming out of those three speakers. It was more than being in the record', ${ }^{28}$

The quotation here is from Larry Levine who worked on Spector's productions as the engineer. Brown tells us that: 'Spector liked to record and to mix at a deafening volume. ${ }^{29}$ The 'Wall of Sound' was Spector's auditory overdetermination of love as utopian fantasy. Thomas Ward, for example, describes 'He's Sure The Boy I Love' as 'a simple teen love song' which Spector transforms into 'something huge and gothic. ${ }^{30}$ It is no wonder that Spector took it upon himself to rename the lead singer of the Crystals, Darlene Wright, as Darlene Love for the release of '(Today I Met) The Boy I'm Gonna Marry,' a Greenwich/Powers/Spector composition which reached number 39 in 1963, a name by which she has remained known for the rest of her career.

In 1964, and through 1965, right at the end of the era of the dominance of the Brill Building's music, Barry and Greenwich supplied songs for another girl group, the Shangri-Las. The Shangri-Las were Jewish: sisters Mary and Betty Weiss and twins Marge and Mary Ann Ganser. They all came from Cambria Heights in Queens. I will write more about them later. Here, though, we can comment on their name. Shangri-La is the name of the fictional utopia created by James Hilton in his novel, Lost Horizon, published in 1933. In 1937 Frank Capra directed a film version of the novel. In Shangri-La life is extended and people remain youthful much longer than elsewhere. The name rapidly took on the connotations of an earthly paradise. The Shangri-Las' name, then, signifies both the fantasy of teenage pleasure and of the life of suburbia where, as we shall see, young couples predominated and older people were rare. Taking on such a name, the Shangri-Las immediately positioned themselves differently to the African-American girl groups with anodyne names like the Shirelles or the Ronettes, or even the Crystals.

The Shangri-Las' image played against their name. They were constructed as 'bad girls,' dressing accordingly in tight sweaters and high boots. Barry and Greenwich co-wrote their most well-known song, 'Leader Of The Pack,' with George 'Shadow' Morton (who is not Jewish), an old school-friend of Greenwich who managed the group, produced the recordings and also wrote some of the songs. 'Leader Of The Pack' was quite typical of the doom, and often death, laden songs the group released. Thematically similar to Leiber and Stoller's 'Black Denim Trousers,' 
about a girl who is forced by her parents to break up with her bikie boyfriend who then crashes his bike and dies, the Shangri-Las, with Mary Weiss' heart-felt lead vocal, sing the song with melodramatic urgency. Where nine years earlier Leiber and Stoller, and the Cheers, played the theme of the death of the rebel bikie for comic effect, now Weiss and the other Shangri-Las sing with a melodramatic intensity that expresses the personal anguish of a love cruelly snatched away and that, with the boy's death, can never be again. The Shangri-Las were signed to Leiber and Stoller's record label, Red Bird. Their final single for the label, 'Past, Present and Future,' was co written by Leiber. It reached number 59 on the singles chart in 1966.

\section{Suburbia}

After the Second World War, suburbia became the built environment expression of the American Dream. Kenneth T. Jackson writes that after the war, 'because of mass production techniques, government financing, high wages, and low interest rates, it was quite simply cheaper to buy new housing in the suburbs, than it was to reinvest in central city properties or to rent at the market price. ${ }^{31}$ Samuel C. Heilman tells us that: 'Between 1948 and 1958, twelve million Americans moved to the suburbs' and that 'between 1950 and 1955, suburbs grew seven times as fast as America's central cities. ${ }^{32}$

One of the most extraordinary suburban developments was built on Long Island in the Town of Hempstead. Starting in 1946 Abraham Levitt, and his sons William and Alfred, began building Island Trees, subsequently renamed Levittown on what had been 4,000 acres of potato farms. By 1960 Levittown had 82,000 inhabitants, almost all of them young married couples. Jackson writes that, 'so many babies were born to them that the suburb came to be known as "Fertility Valley" and "The Rabbit Hutch", 33

In Anglophone thought suburbia has always had a utopian quality to it. Describing the origins of suburbia on the outskirts of late eighteenth century London, Robert Fishman explains that: 'There, within easy commuting distance to the city by private carriage, these merchants and bankers could construct their "bourgeois utopia" of leisure, neighborliness, prosperity, and family life. ${ }^{34}$ Jackson glosses this utopian quality for post-Second World War America: 'Suburbia symbolizes the fullest, most unadulterated embodiment of contemporary culture; it is a manifestation of such 
fundamental characteristics of American society as conspicuous consumption, a reliance upon the private automobile, upward social mobility, the separation of the family into nuclear units, the widening division between work and leisure, and a tendency towards racial and economic exclusiveness. ${ }^{35}$

Given this utopian element, if white American expectations for suburbia were very high, they were even higher for Jews. The first point to make, though, is about the whiteness and the middle-classness, of post-Second World War suburbia. Jackson argues that, 'perhaps [the] most important characteristic of the post-war suburb was economic and racial homogeneity. ${ }^{36}$ Writing about the massive expansion of postSecond World War suburbia he explains that:

'The post-1945 developments took place against a background of the decline of factory-dominated cities. What was unusual in the new circumstances was not the presence of discrimination-Jews and Catholics had been excluded from certain neighborhoods for generations - but the thoroughness of the physical separation that it entailed. ${ }^{37}$

Levitt, who was Jewish, would not sell his houses to African Americans fearing the loss of sales to whites: 'Not surprisingly, in 1960 not a single one of Long Island Levittown’s 82,000 residents was black. ${ }^{38}$ However, many of them were Jewish.

In 1959 Albert Gordon published a book titled Jews in Suburbia. Gordon assumed Jews to be white and the Jewish difference to be religious. He explained what had been happening in New York this way:

'In New York City, grave concern has been expressed over the years because of the infiltration of Negroes and Puerto Ricans into neighborhoods that had been all white. Because standards and habits are different and because people like to live among their own kind, New Yorkers have been in mass flight from Manhattan to the suburbs. ${ }^{39}$

Gordon goes on to present statistics that show that the number of people designated as non-white in the five boroughs between 1950 and 1957 increased by 41.3 per cent while the number of people identified as white decreased by 51.9 per cent. Through the 1950s there was an increasingly defined organisation of the American built 
environment between an African-American, and other non-white, inner city and a white suburbia.

What, then, was the white, suburban view of the city? Fishman puts it like this: 'If suburbia was the bourgeois utopia, it existed in an inevitable tension with the bourgeois hell—the teaming world of the urban slum—-from which suburbia could never wholly escape because the crowded city was the source of its prosperity. ${ }^{40}$ In the post-war American context, this conceptual division was also racialised. In this context we can begin to think about the reception of the Mann/Weil composition 'Uptown,' and the Aldon Music writers' other songs with an urban setting.

Written by two Jews, produced by another, Spector, and sung by the AfricanAmerican girl group, the Crystals, 'Uptown' reached number 13 on the pop chart in 1962. Lyrically, 'Uptown' is a song of social observation. It describes a man who works downtown, 'Where everyone’s his boss' but who, each evening, comes back uptown, 'to my tenement/Uptown where folks don't have to pay much rent.' Emerson places the song within Mann and Weil's own biographies of social conscience and, more broadly, within the left-wing humanist tradition of New York Jewry. ${ }^{41}$ However, there is more going on than this. The song functions in terms of the binary built environment structure outlined above which, by the early 1960s was well established and completely taken for granted. The man works in the city and lives in a tenement. Where fifty years earlier it would have been assumed, most probably, that he was Jewish, now, in the early 1960s, it goes without saying that he is African American. And not saying makes the song less confrontational while reinforcing the audience's position as 'white.'

Working downtown, it would also be assumed that, in the black/white divide, the man's boss would be 'white' — and included in white here is Jewish. Moreover, this white boss would, it could be assumed, live in suburbia, far away from this urban hell. By focusing on the life experience of the Other, personified in the voices of the Crystals who, in their singing, take on the first person position of the lyrics, the song emphasises the whiteness of its audience, including its Jewish audience and its Jewish writers and producer.

'On Broadway' was also written by Mann and Weil, this time in collaboration with Leiber and Stoller who also produced it. 'On Broadway' reached number 9 in 
1963. The song is about a man who travels to New York because he wants to be a star on Broadway. However, he has no money and the song constructs a binary between the glitzy magic of Broadway and this struggler who can't get enough to eat. Given that the song was performed by the Drifters, and that Stoller 'gave the melody a bluesier feel,' ${ }^{42}$ listeners would 'know' the man is African-American. At this point the song's poor/rich binary is racialised. It is a poor Black man trying to make it on Broadway which, it is taken for granted, is owned and run by Jews and whites. In this binarised structure, these Jews, like those in 'Uptown,' are whitened against the focus on the African American and his predicament.

Between these two hits, the Drifters' version of 'Up On The Roof,' written by Goffin and King and produced by Leiber and Stoller, climbed to number 5 on the pop chart. 'Up On The Roof' is an out and out romanticization of African-American urban working-class life imagined as hell by those living in suburbia imagined as bourgeois utopia. The ideological force of this structure is fully apparent in the final verse where, in this romanticization, hell is transformed into paradise: 'Right smack in the middle of town/I've found a paradise that's trouble proof (up on the roof).' Once again, sung by an African American voice which embodies the lyrics' first person narrator, Jews become whitened in the mass of suburban listeners.

While it does not have an urban setting, the song which, by default, illustrates this whitening structure best is another Mann/Weil composition. As Emerson puts it, Weil's original lyrics to 'Only In America' were, 'a sarcastic indictment of racial discrimination that made Bob Dylan's “Blowin' in the Wind," written the previous year and shortly to become a hit single for Peter, Paul and Mary, seem circumspect. ${ }^{43}$ Leiber and Stoller told Mann and Weil that the song was 'too inflammatory ever to get airplay' and suggested that they rewrite it as 'a paean to upward social mobility' which, when sung by the Drifters would carry the irony, for those aware (or who could be bothered to think that critically), that upward mobility for African Americans such as the Drifters was completed blocked—as blocked, we might add as moving to the suburbs. After being recorded by the Drifters in its new version, Atlantic Records refused to release it because it was felt to be insulting to African Americans. The song was subsequently recorded by another group of Leiber and Stoller protégés, Jay and the Americans - who happened to be Jewish. It became a hit. More: 'When the group performed in Florida, they were astonished to find venues filled with Cubans. 
“"They couldn’t speak English,” [Kenny] Vance [a member of Jay and the Americans] said, “but they learned 'Only In America' phonetically. ${ }^{44}$ Where songs like 'Uptown’ and “Up On The Roof,' sung by African Americans, whitened Jews by concentrating on the African-American Other, a song as inherently celebratory as 'Only In America' could become a hit for a Jewish group passing as white and, indeed, aid Jewish assimilation into American whiteness - an assimilation which enabled the song to make sense for the Jewish experience. At the same time, where, when sung by African Americans, the song cruelly emphasised American racial prejudice, when listened to by Cuban migrants it expressed for them the American dream of the possibility of individual achievement.

I have been implying that Jews were whitened as they moved to the suburbs. We now need to examine this process in more detail. Jews moved out of the cities later than WASPs. The 1957 United States' census 'revealed that 96 per cent of the approximately five million American Jews were still living in cities, 87 per cent in urban areas of over a quarter of a million people. ${ }^{45}$ However, by 1965, 'about a third of all American Jews [had] left the big cities and established themselves in the suburbs. ${ }^{46}$ One reason Jews moved so slowly into the suburbs had to do with the process that whitened Jews. As Karen Brodkin remarks:

'[Our parents] were all children of immigrants who grew up in New York in the 1920s and 1930s, which was the high tide of American anti-Semitism, a time when Jews were not assigned to the white side of the American racial binary.... We, their children, grew up as white, middle-class suburbanites. ${ }^{47}$

Brodkin argues that: 'The economic mobility of Jews and other Euro-ethnics derived ultimately from America's post-war economic prosperity and its enormously expanded need for professional, technical, and managerial labor, as well as on government assistance in providing it. ${ }^{48}$ Jewish economic, and social, upward mobility was a consequence of the expansion of the American economy. Jews were whitened as a part of this process and moving to the suburbs was a key element. In becoming middle class, Jews internalised the ideology of individualism: 'Their reinvention of themselves as individuals pursuing happiness dovetailed neatly with the aspirations of all suburbanites. 49 
Joyce Antler captures well the especially Jewish aspect to the utopian thinking that was so central to the Jewish movement to the suburbs:

'Though they still remained an urban people, in the two decades after the war, about a third of American Jews-even the fictional [television sit com] Goldberg family-had left the city for the suburbs, the new “middle-class Shangri-La[s]”...For Marjorie Morningstar and thousands like her, the new communities were "a symbol of Utopia”a "sign of success, prestige, money, power and security"., 50

Suburbia was thought of as an American Shangri-La. After all, in the written prologue at the beginning of the film of Lost Horizon, we are asked, 'haven't you ever dreamed of a place where there was peace and security, where living was not a struggle but a lasting delight?' Calling themselves the Shangri-Las, the Weiss and Ganser sisters from Queens signalled this reference in their disillusioned regret for a lost American utopia.

\section{Blackface, Marking Jewishness, and the Brill Building Sound}

Commenting on the Jewish use of blackface in the early part of the century, and with particular reference to The Jazz Singer, Michael Rogin writes that: 'Blackface may seem not to express Jewishness at all but to hide it, so that even your own mother wouldn't know you. 51 He argues that: 'Switching identities, the jazz singer acquires exchange value at the expense of blacks. ${ }^{, 52}$ In the early part of their careers Leiber and Stoller, and Doc Pomus, were writing for African-American artists and audiences. In this sense they blackened themselves. Structurally, Leiber and Stoller, and Pomus, aligned themselves with African Americans.

Nevertheless, we also need to remember the image that Emerson gives us of Stoller 'putter[ing] on an upright piano in his parents' apartment' '[u]nder the gaze of a photograph inscribed by George Gershwin' ${ }^{53}$ and Emerson's point that 'Leiber and Stoller held Porter and Gershwin in such high regard that they belittled their own compositions. ${ }^{54}$ In his book on how Jewish and African-American musical relations have been thought about Jeffrey Melnick writes that: '[Irving] Berlin and Gershwin (and Jolson and so on) needed African Americans as both source of musical inspiration and object of representation. ${ }^{55}$ While Leiber and Stoller drew on their knowledge of African-American culture, writing in a Black idiom and working with 
Black artists for Black audiences, they looked up to a Jewish composer who had reworked African-American musical forms for a white audience.

By mid-way through the career of the Coasters, as we have seen, Leiber and Stoller started writing for a white, teenage audience. This was also the audience for Don Kirshner's composers at Aldon Music. Blackface now becomes a little more complicated. It is, if you like, blackface by proxy. At a time of increasingly extreme geographical segregation between Black and white, as we have seen, and when Jews are being whitened, the Brill Building Jews mask their identities, and, to use Rogin's expression, gain exchange value, through the African Americans who sing their songs. Gershwin's first really popular song, we should remember, which he co-wrote with Irving Caesar, was the blackface 'Swanee,' performed and recorded by Al Jolson in 1920 for a white audience. It referenced back to Stephen Foster's classic blackface song, 'Old Folks At Home'. The Drifters, the Crystals, the Ronettes, became the Jewish blackface as Jews were whitened during their movement to suburbia.

Things, though, are more complicated. At the same time that Jews were moving to the suburbs and becoming whitened, as we have already found Heilman arguing, they wanted to retain the mark of their Jewishness. The same argument can be made for the Brill Building sound. These songs may have been made for white teenagers by Jews masquerading behind African-American artists but, was there nothing to mark these songs as Jewish? Melnick remarks on the opening clarinet passage of Gershwin's Rhapsody in Blue that, 'listeners today might hear more klezmer than jazz in it ${ }^{56}$ and there are references to klezmer in Artie Shaw's Gramercy Five sessions. There is no klezmer in the Brill Building sound. What there is, though, running through the Drifters' music, many of Spector's productions, some of Pomus and Shuman's songs and some of the songs of the Aldon Music composers, is an insistent Latin rhythm, mostly baion but occasionally rumba or even cha-cha. Pomus described the songs he and Shuman had written for the Drifters as 'Jewish Latin. $^{57}$ In Always Magic in the Air, Emerson has a chapter with this title on the Latin influence in the Brill Building sound.

What is going on here? First of all, we need to remember the importance of what Josh Kun calls 'the Latin Craze of the 1950s' when, as he goes on to write, 'it was hard for anyone, Jew or otherwise...to not rethink the world in mambo time. ${ }^{58}$ Kun discusses, in fascinating detail, the especially Jewish preoccupation with Latin 
rhythms during this time. Mamboniks, as they were called, were everywhere. At the heart of Kun's argument is the idea that, 'many Jews in Latin music were rejecting a total recuperation into whiteness while refusing to perform their Jewishness in traditional ways ${ }^{, 59}$ or, as he describes two Jews in Oscar Hijuelos' novel The Mambo Kings Play Songs of Love (1989):

'Jews who perform their Jewishness, and not their whiteness, through Latino musical idioms. By "going Latin,” they "go Jewish” while not "going white", 60

Much the same argument can be made for the Brill Building sound. The Jewishness of the music is marked not by klezmer, which would have been both too obvious and too Jewish at a time when Jews were being whitened and, they thought, accepted and assimilated. The Latin influence signals simultaneously Jewish difference and Americanization. The song that epitomises this is the Leiber and Spector composition, 'Spanish Harlem.' In the lyrics, the 'red rose' that grows there functions as a metaphor for a Puerto Rican girl. The metaphor, and its object, can be read as a commentary on the 1950s Jewish infatuation with Latin. Sung by Ben E. King, immediately after leaving the Drifters, 'Spanish Harlem,' with its baion rhythm, reached number 15 in the Rhythm and Blues chart and number 10 in the pop chart. In Jewish Latin, it is the Jewish composers and producers who provide the link between the African-American sound of the artists and the Latin rhythmic inflection. An actual synthesis of Latin and African-American music would have to wait until the mid-1960s and the evolution of the boogaloo-usually traced to Joe Cuba's 'Bang Bang' in $1966 .^{61}$

\section{Love and Americanization}

I have mentioned earlier the importance of love in the lyrics of the Brill Building writers, especially as the basis for a utopian future. We must now expand on this. For Jews, the acceptance of the practice of love as the foundation for marriage was a key development in the process of Americanization. Migrant Jews in the early years of the century came from a culture where marriages were arranged and where the marriage broker, schadchen, was of central importance. Riv-Ellen Prell quotes from the letter of a young migrant woman in a story, 'The Miracle,' by Anzia Yezierska: 
'America is a lover's land. In America millionaires fall in love with the poorest girls. Matchmakers are out of style, and a girl can get herself married to a man without the worries for a dowry. ${ }^{\text {, } 2}$

Yezierska’s story is from around 1920.

In the United States the convention of dating, where boys asked girls out, was becoming established in the first decades of the century. ${ }^{63}$ In the Yiddish culture from which the migrants came, the custom of arranged marriages continued until the Second World War. Prell quotes a memoir written in Minsk in 1939:

'At the time there was no other way than through the medium of a match maker or marriage broker by which a girl of the Jewish middle class might obtain a husband. No one ever thought of such a thing as love. ${ }^{64}$

In the United States young women especially, it would seem, found the freedom to establish relationships based on love to be very attractive. Prell writes succinctly that: 'Americanization implied romantic love for Jews as surely as it required the use of English. ${ }^{65}$

However, the match maker did not immediately disappear. As late as 1938 the New Yorker published an interview with Louis Rubin of Rubin's Prominent Matrimonial Bureau who complained that timid clients 'insist on working a certain amount of romance into the thing, for which Rubin blames poets, songwriters, and movies. ${ }^{66}$ Clearly love, and marital relationships based on love, remained at least to some extent, a contested issue right up to the Second World War. At the same time, and indeed most likely because it continued to be contested, the practice of love, and the establishing of relationships based on love, was a crucial aspect of Americanization. For first, and indeed for second, generation Jewish migrants, love had a utopian quality to it. Experiencing it marked a person as American.

In the 1950s there were other developments that contributed to the importance of love as a topic in popular song. The establishment of the teenager as a consumer category was one. Palladino writes that, in 1964 there were 22 million teenagers in the United States who comprised a \$12 billion consumer market which spent around $\$ 100$ million a year on records. ${ }^{67}$ Another was the decline in the age of marriage. Beth Bailey tells us that: 
'By 1959, fully 47 per cent of all brides married before they turned nineteen, and the percentage of girls between fourteen and seventeen who were married had jumped one-third since 1940. Newsweek reported in 1957 that 16 percent of America's three million college students were married. ${ }^{68}$

In The Feminine Mystique, Friedan wrote that, by the end of the 1950s, fourteen million girls were engaged by the time they were seventeen. ${ }^{69}$ When Kirshner started employing his writers at Aldon Music they knew the teenagers they were writing for because they were, themselves, teenagers or in their early twenties.

At the same time, I am arguing, there was an overdetermination to the Brill Building writers' preoccupation with love. If the practice of love as a force in relationships marked their migrant grandparents, and sometimes their parents, as Americanized, then love now marked the transition to whiteness, and the utopian suburbs. Love signalled the Jewish entry into middle class, white suburban society. In both cases love carried the overdetermining utopian desire for Americanization and for acceptance.

Pomus and Shuman wrote some of these fantasies of romantic love. Dion and the Belmonts, for example, reached number 5 in 1959 with their 'Teenager In Love.' Emerson writes that, 'fearfulness, fragility, and tremulous romanticism are at the heart of many of Pomus and Shuman's best ballads. ${ }^{70}$ However, Neil Sedaka and Howard Greenfield's songs are, perhaps, the best example of the Jewish tendency to think of love in the terms of utopian fantasy. Sedaka himself, for example, had hits with 'Breaking Up Is Hard To Do,' number 1 in 1962, 'Happy Birthday Sweet Sixteen,' number 6 in 1962, and 'Next Door To An Angel,' number 5 in 1962. Emerson describes these songs:

'There are no blue notes in Sedaka's cotton-candy scale, no traces of actual experience in Greenfield's imagery of angels and devils and cutie-pies. These are fantasies whose only urgency is their extreme eagerness to please. ${ }^{71}$

The consistent popularity of these songs, and others like them, is remarkable. These fantasies of love, overdetermined by the dreams of Jewish migrants, first to the United 
States, then to the suburbs, spoke powerfully also to the dreams of white American teenagers entering the world of dating.

\section{Unrequited Love, Disillusionment and the Shangri-Las}

Just as Jewish migration to the suburbs was peaking in the early 1960s, disillusionment was setting in. As we have seen, Friedan expressed it well for women, both white and Jewish. However, what Jews discovered was that being accepted as white did not bring cultural acceptance. Discussing an opinion poll from 1959, Prell notes that, 'white American prejudices persisted. This group did not support discrimination against Jews; they simply held anti-Semitic beliefs. ${ }^{72}$ The suburban WASP did not want to mix with their newly whitened Jewish neighbours:

'Socializing and intimate friendships were slow to transcend religious boundaries. Young Jewish families asserted that they felt unwelcome in non-Jews' homes. ${ }^{73}$

In terms all the more evocative in light of the argument I am making here, Prell writes:

'The mass immigration of Jews was long over. Nevertheless, with suburbanization, America’s “Jewish problem” re-emerged. , 74

The upwardly mobile suburban Jews were whitened but they were not culturally accepted.

A love, in which the dream of Americanization and reciprocal acceptance was played out, remained unrequited. Sedaka and Greenfield's songs no longer made the charts, and they stopped writing them. People no longer bought Spector's fantasies of perfect love. Barry and Greenwich stopped writing with Spector for the Crystals and the Ronettes and started writing with "Shadow" Morton for the Shangri-Las. We can now begin to appreciate the full irony of this Jewish group's name, invoking utopian suburbia yet singing songs of family destruction. And Greenwich, we can remember, was the only one of the Aldon Music writers actually to grow up in the suburbs, in Levittown where her family moved in 1951 when she was eleven.

I have already mentioned 'Leader Of The Pack,' the song about the boyfriend from the wrong side of the tracks who dies in a motorbike accident after he is told his girlfriend's parents forbid them to see each other. It reached number one in 1964. In 
1965, the Shangri-Las’ version of Barry and Greenwich’s 'Give Us Your Blessings' got to number 29. In this song the two teenagers die in a car crash while eloping because their parents refuse permission for them to marry. Later in 1965, the group reached number 6 with Morton's 'I Can Never Go Home Anymore,' a song about a girl who runs away from home because her mother forbids her to see a boy because she thinks her daughter is too young. The girl forgets the boy and her mother 'grew so lonely/the angels took her for their friend.' We are a long way from the utopian romance in the Sedaka and Greenfield songs. For the Shangri-Las love is dysfunctional. It produces personal anguish, wrecks families and brings death.

The last time the Shangri-Las got near the higher reaches of the chart was with a spoken, elegiac song, wringing with sadness and lost dreams written by Artie Butler, Leiber and Morton. 'Past, Present, Future' got to number 59 in 1966. Richie Unterberger writes about the song's 'implied subject matter of someone who might not only be recovering from a failed romance, but from a sexual assault' and describes 'Weiss' almost panicked warnings not to touch her there, as that would never happen again. ${ }^{75}$ Love no longer brings utopian fulfilment but, in this final Shangri-Las' irony, loneliness, disillusionment and date rape.

In 1964, the same year that the Shangri-Las had their first hits, as teenagers stopped buying his pathologically overwhelming fantasies of love, Spector produced the most popular recording of his career. It was, however, not a joyous song of love found. Bill Medley's baritone came in a deep, agonising moan out of what seems like no longer a Wall of Sound but a huge, indeed infinitely large, cavern (Emerson describes the impression as being of an 'echoing cathedral ${ }^{76}$ but the production's space is far larger than this). It is the sound of loss. Broadcast Music Inc cites the Righteous Brothers' 'You've Lost That Lovin' Feeling' as the most played song on American radio in the twentieth century. ${ }^{77}$ Released in December, the record topped the Billboard chart for two weeks in 1965. The lyrics were written by Mann and Weil with Spector. When Medley sings 'something beautiful's dying,' the affect is devastating. More than just the end of a relationship, the recording is the sound of the end of a dream.

Emerson describes Goffin and King’s 'Will You Love Me Tomorrow' as 'set in the real world. ${ }^{, 78}$ The same can be said for one of the pair's last big hits, 'Pleasant Valley Sunday,' released by the Monkees in 1967 and reaching number 3 on the pop 
chart. Sometime in 1963 Goffin and King followed Kirschner, and all those other Jews, into the suburbs. They lived:

'in a boxy house in a new development on a treeless hillside in West Orange, New Jersey. The front doorbell chimed "Will You Love Me Tomorrow," while out back were a pool and barbecue. ${ }^{79}$

Emerson comments that, 'suburban blandeur left them isolated and unstimulated" ${ }^{80}$; two more disillusioned Jews. By 1965, marooned in suburbia, Goffin was suffering mental problems, taking a lot of LSD, and the Goffin and King marriage was breaking down. Pleasant Valley Way was just a few blocks from where Goffin and King lived. 'Pleasant Valley Sunday' is their own, understated, acknowledgement of the loss of the suburban dream. The lyrics set the scene, telling us that: 'The local rock group down the street/Is trying hard to learn their song.' This garage band is disturbing the peace of suburbia with their disillusionment. And, in this suburb as in all the others, there are: 'Rows of houses that are all the same/And no one seems to care' while 'Here in status symbol land/Mothers complain about how hard life is/And the kids just don't understand.' The production, in the light manner typical of the Monkees' style of bubblegum pop, belies the anguish and disillusionment in the lyrics.

The Brill Building sound was Jewish-American music. Aesthetically it was connected with the Tin Pan Alley music of a generation earlier which had also been written by Jews. The music that came from 1619 and 1650 Broadway, especially the songs written by the composers of Aldon Music, expressed the desires of teenagers but they were also located in the dreams of American Jews for acceptance in middle class, white American society. These were songs of love and love was not only central to the ways that American teenagers understood and negotiated relationships, it was also foundational to the Jewish experience of Americanization.

Through the decade between around 1955 and 1965, as Jews in the United States were given entry to whiteness and to the rewards that being white brought such as suburban, middle-class life, the Brill Building songs provided a soundtrack of hope and joy. However, by the early 1960s, large numbers of white, middle-class Americans were beginning to acknowledge that, rather than a utopia, suburbia was a place of confinement where women, especially, had great difficulty leading fulfilling 
lives. Teenagers turned away from the love songs of the Brill Building sound and started buying the music of the garage bands and the protest songs of Bob Dylan. Within this context it is no wonder that the FBI investigated the Kingsmen's 'Louie Louie' as a song subversive of the American way of life! For Jews, this situation was compounded as the achievement of the suburban dream turned into the realisation that whiteness did not bring social acceptance. As the dream died, so the songs that came from the composers at Aldon Music started to express this Jewish disenchantment in songs about the loss of love and relationships that destroyed families. Spector's last great production of this era, Ike and Tina Turner's 'River Deep-Mountain High,' is a love song but it sounds like a plea of desperate yearning, a cry for something that the singer knows is already lost.

$1 \quad$ Ken Emerson Always Magic in the Air:The Bomp and Brilliance of the Brill Building Era (New York: Viking, 2005), p. xii.

2 Mick Brown Tearing Down the Wall of Sound: The Rise and Fall of Phil Spector (London: Bloomsbury, 2007), p. 82.

3 Ian Inglis " "Some Kind of Wonderful": The Creative Legacy of the Brill Building,' in American Music, vol 21, no 2 (2003): 218.

$4 \quad$ Inglis “"Some Kind of Wonderful”,' p. 217.

$5 \quad$ Brown Tearing Down the Wall of Sound, p. 82.

$6 \quad$ Neil Gabler An Empire of Their Own: How the Jews Invented Hollywood (New York: Doubleday, 1989), p. 7.

$7 \quad$ Inglis “"Some Kind of Wonderful”,' p. 214.

$8 \quad$ Grace Palladino Teenagers: An American History (New York: Basic Books, 1996), p. 132.

$9 \quad$ Michael Billig Rock'n'Roll Jews (Syracuse, NY: Syracuse University Press, 2001), p. 91.

Quoted in Billig, Rock'n'Roll Jews, p. 91. 
Emerson Always Magic in the Air, p. 195.

Inglis “ “Some Kind of Wonderful”,' p. 221.

Philip Ennis The Seventh Stream: The Emergence of Rocknroll in American

Popular Music (Middletown, Conn.: Weslyan University Press, 1992), p. 277.

On the history of 'Louie Louie' see Dave Marsh Louie Louie: The History and Mythology of the World's Most Famous Rock'n'Roll Song (Ann Arbour: University of Michigan Press, 2004).

Michael Hicks Sixties Rock: Garage, Psychedelic, and Other Satisfactions (Urbana: University of Illinois Press, 1999), p. 25.

On Friedan's life see Daniel Horowitz Betty Friedan and the Making of The Feminine Mystique: The American Left, the Cold War, and Modernism Feminism (Amherst: University of Massachusetts Press, 1998).

Betty Friedan The Feminine Mystique (New York: Norton, 1963), p. 15.

Emerson discusses this history in Always Magic, p. 8.

Emerson Always Magic in the Air, p. 9.

All this information comes from Emerson Always Magic in the Air, p. 9.

Emerson Always Magic in the Air, p. 63

Emerson Always Magic in the Air, p. 53.

All this information is from Emerson Always Magic in the Air, p. 41.

Brown Tearing Down the Wall of Sound, p. 27.

Brown Tearing Down the Wall of Sound, p. 38.

Brown Tearing Down the Wall of Sound, p. 38.

Brown Tearing Down the Wall of Sound, p. 1.

Brown Tearing Down the Wall of Sound, p. 118.

Brown Tearing Down the Wall of Sound, p. 118.

Thomas Ward, Review of 'He's Sure The Boy I Love' on AllMusic Guide at: http://wc02.allmusic.com/cg/amg.dll?p=amg\&sql=33:gzfoxq9gld6e .

Kenneth T. Jackson Crabgrass Frontier: The Suburbanization of the United States (New York: Oxford University Press, 1985), p. 241. 
Samuel C. Heilman Portrait of American Jews: The Last Half of te 20 th Century (Seattle: University of Washington Press, 1995), p. 10.

Jackson Crabgrass Frontier, p. 235.

Robert Fishman Bourgeois Utopias: The Rise and Fall of Suburbia (New York: Basic Books, 1987), p. 10.

Jackson Crabgrass Frontier, p. 4.

Jackson Crabgrass Frontier, p. 241.

Jackson Crabgrass Frontier, p. 241.

Jackson Crabgrass Frontier, p. 241.

Albert I. Gordon Jews in Suburbia (Boston, Mass.: Beacon Press, 1959), p. 9.

Fishman Bourgeois Utopias, p. 135.

Emerson Always Magic in the Air, p. 135-136.

Emerson Always Magic in the Air, p. 138.

Emerson Always Magic in the Air, p. 138.

Emerson Always Magic in the Air, p. 140

Heilman Portrait of American Jews, p. 20.

Arthur Hertzberg The Jews in America quoted in Heilman Portrait of American Jews, p. 21.

Karen Brodkin How Jews Became White Folks And What That Says About Race in America (New Brunswick: Rutgers University Press, 1998), p. 2.

Brodkin How Jews Became White Folks, p. 37.

Heilman Portrait of American Jews, p. 19.

Joyce Antler You Never Call! You Never Write!: A History of the Jewish Mother (New York: Oxford University Press, 2007), p. 102.

Michael Rogin Blackface, White Noise: Jewish Immigrants in the Hollywood Melting Pot (Berkeley: University of California Press, 1996), pp. 99-100.

Rogin Blackface, White Noise, p. 100.

Emerson Always Magic in the Air, p. 7.

Emerson Always Magic in the Air, p. 51. 
Jeffrey Melnick A Right to Sing the Blues: African Americans, Jews, and American Popular Song (Cambridge, Mass.: Harvard University Press, 1999), p. 41.

Melnick A Right to Sing the Blues, p. 47.

Emerson Always Magic, p. 126.

Josh Kun 'Bagels, Bongos, and Yiddishe Mambos, or The Other History of Jews in America' in Shofar, vol 23, no 4 (2005): 51.

Kun 'Bagels, Bongos...’, p. 64.

Kun ‘Bagels, Bongos...’, p. 65.

Juan Flores From Bomba to Hip-Hop: Puerto Rican Culture and Latino Identity (New York: Columbia University Press, 2000), Chapter 5 'Cha-Cha with a Backbeat: Songs and Stories of Latin Boogaloo.'

Quoted in Riv-Ellen Prell Fighting to Become Americans: Jews, Gender, and the Anxiety of Assimilation (Boston, Mass.: Beacon Press, 1999), p. 61.

On the history of dating see Beth Bailey From Front Porch to Back Seat: Courtship in Twentieth-Century America (Baltimore: Johns Hopkins University Press, 1988).

Quoted in Prell Fighting to Become Americans, p. 63.

Prell Fighting to Become Americans, p. 66.

Quoted in Jenna Weissman Joselit The Wonders of America: Reinventing Jewish Culture, 1880-1950 (New York: Henry Holt and Company, 1994), p. 12.

Palladino Teenagers, p. 195.

Bailey From Front Porch to Back Seat, p. 43.

Friedan The Feminine Mystique, p. 16.

Emerson Always Magic in the Air, p. 49.

Emerson Always Magic in the Air, p. 105.

Prell, Fighting to Become Americans, pp. 157-158

Prell, Fighting to Become Americans, p. 159.

Prell, Fighting to Become Americans, p. 158. 
Richie Unterberger 'Past, Present, Future' on the AllMusic Guide website at: http://wc02.allmusic.com/cg/amg.dll?p=amg\&sql=33:jxftxxt5ldte .

76 Emerson Always Magic in the Air, p. 204.

77 Broadcast Music Inc. website at: http://www.bmi.com/news/entry/232893 .

Emerson Always Magic in the Air, p. 105.

Emerson Always Magic in the Air, p. 191.

80

Emerson Always Magic in the Air, p. 191. 